\title{
LA POLÉMICA ILUSTRADA SOBRE LA RELIQUIA DE LA SANTA FAZ DE ALICANTE: UN ATAQUE A LA COMPAÑIA DE JESÚS
}

\section{Enrique CUTILLAS BERNAL}

Universidad de Alicante

A mediados del siglo XVIII tuvo lugar en Alicante una dura controversia entre dos religiosos que afectó a la tradicional fe que los alicantinos tenian depositada en la reliquia verónica conservada en el cercano monasterio de la Santa Faz.

Pese a ser contemporánea a los hechos, la Crónica del padre Maltés ' nada dice sobre este acontecimiento, posiblemente preocupado por no remover una disputa que ya había dañado las creencias de muchas gentes, o bien por no querer inmiscuirse en un problema que, en el fondo, no era otra cosa que el larvado ataque de algunas Ordenes religiosas contra la Compañía de Jesús.

Un siglo más tarde, la Crónica de Viravens ${ }^{2}$ daba cuenta de los hechos, pero dándole un enfoque diferente al que realmente tenian, quizás debido a conocer solamente la versión de una de las partes, la del jesuita Fabiani, depositada en el Archivo Municipal de Alicante.

La amabilidad del Dr. Antonio Mestre nos puso en contacto con los Fondos Mayansianos, gracias a los cuales pudimos conocer los motivos de la otra parte disputante, al estudiar la correspondencia mantenida entre el presbitero Sales, Cronista del Ayuntamiento valenciano y del convento trinitario de la ciudad del Turia, y don Gregorio Mayans.

El conocimiento de esta correspondencia entre Sales y Mayans, junto a las continuadas alusiones que en ella aparecen sobre las pretensiones del prior del 
convento trinitario de Játiva acerca de la disputa, nos permitió profundizar en los motivos encubiertos que suscitaron la vieja polémica y comprobar cómo, lo que comenzó siendo una opinión personal del presbítero sobre el sermón impreso del jesuita Fabiani, se convirtió en un arma contra las ideas representadas por la Compañía.

El culto a la Santa Faz venía celebrándose desde 1525 por concesión Viva Vocis Oraculo del papa Clemente VII. Se trataba de un rezo propio con rito de Doble Mayor que se ofrecia a la reliquia cada 17 de marzo, en el día de su fiesta. Ante la proliferación de concesiones salidas de Roma sin una autentificación papal que las legitimara, Urbano VIII, aplicando la reforma de Pio V, decidió cortar estos abusos aboliendo por breve de 20 de diciembre de 1631 todos aquellos rezos y provilegios concedidos por Roma sin la rúbrica pontificia.

El breve no fue bien acogido en Alicante y el oficio siguió celebrándose cada 17 de marzo, pese al intento del franciscano Jerónimo Sánchez de Castelar, que para justificar la abolición de Roma declaraba en el sermón del dia de la fiesta de 1635 que el Papa no permitía ese culto a la reliquia por ser una copia de la conservada en Roma.

Aunque no pudimos constatarlo documentalmente, una serie de indicios nos parecen indicar que, bajo el Patronato del Consell, el monasterio mantuvo durante largos años la celebración del rezo, haciendo caso omiso al breve de Urbano VIII, como haria más tarde con la decisión sinodal de cambiar el día de la fiesta y como hubjese ocurrido con el cambio ordenado por el obispo Elias Gómez de Terán, si no hubiera mediado una Real Orden que obligaba al Ayuntamiento a acatar el Sagrado Ceremonial dictado por la jerarquía eclesiástica.

Pero pese a continuar el culto abolido, el hecho de no aceptarlo Roma significaba el reconocimiento de que la reliquia alicantina no era verdadera, sino copia de la depositada en el Vaticano, lo que llevaría al Consell de Alicante a mantener largas y costosas negociaciones desde 1685 a 1697. Pese a las influencias interpuestas, todo resultaria infructuoso ante una Sagrada Congregación de Ritos dominada por cardenales como Noris, Casanate o Sáenz de Aguirre.

\section{El marco coyuntural}

Antes de adentrarnos en el nucleo de este trabajo y para una mayor claridad, seria conveniente retroceder cronológicamente a los años anteriores a la Polémica y conocer así el contexto en que se desarrollarian los acontecimientos.

Los diversos conventos de religiosos asentados en Alicante, venían percibiendo desde su fundación constantes ayudas por parte de la Ciudad, aunque 
tenemos documentada una marcada preferencia municipal por el convento franciscano de Nuestra Señora de Gracia y por el de la Santa Verónica, de clarisas de la Primera Regla. Sobre todo éste último que junto a San Nicolás y la parroquial de Santa Maria, estaban bajo el Patronato del Ayuntamiento.

Los trece años de reinado de Fernando VI representaron un periodo de prosperidad para Alicante, aunque durante estos años se afianzaria la centralización y el control para recortar los abusos y despilfarros de los regidores, que vieron cercenarse muchas de las prerrogativas que venían manteniendo.

El Nuevo Reglamento señalaba las cantidades que podían gastar en fiestas, salarios, gastos ordinarios y extraordinarios, concediendo una cantidad muy inferior a las reconocidas por Carlos II ochenta años atrás. Los regidores se vieron obligados a evitar las limosnas para los conventos, que debían vivir por sí mismos y sólo el de la Santa Verónica percibiría 490 libras anuales a cambio de renunciar a su parte de sisa de la carne.

Se reducian los gastos de fiestas y rogativas con el consiguiente malestar entre los miembros del clero que debian acudir a la Peregrina sin remuneración alguna y veían perder parte de sus ganancias, quejándose de no tener suficiente con las 8 libras concedidas para todos los eclesiásticos, cuando ya eran poco las 12 libras y 6 sueldos que venian recibiendo desde mediado el siglo $\mathrm{XVII}^{3}$.

El descontento de Franciscanos, Capuchinos, Carmelitas, Agustinos y Dominicos iria en aumento a partir de la rogativa de 1760 . Hasta entonces, la obligación tradicional que tenian estas Ordenes de acudir a la procesión oficial que salía desde la Colegial hasta la Misericordia para recibir a la reliquia era compensada con dos libras de limosna a cada convento y, por la designación rotativa de los tres predicadores para los tres días de estancia de la Santa Faz en la Cólegial, por cuyo trabajo recibian 4 libras cada uno de los tres religiosos.

Precisamente en enero de 1760 , el Ayuntamiento decidía traer la reliquia en rogativa pro-plivia, pero con algunas diferencias respecto a anteriores rogativas:

"Minorando las dietas de Dipulados, gastos excesivos y profusión
de comidas, ... asistiendo a esta función graciosamente y sin la
percepción de los derechos que otras veces se les han consigna-
do".

El Cabildo de la Colegial aceptaba acudir a la rogativa sin cobrar por esta vez solamente, siempre que se abonara a los curas y frailes aistentes las cantidades acostumbradas ${ }^{5}$. 
La rogativa se celebraria tinaimente como era costumbre, con comida y limosna para todos los eciesiasticos, abonándose por mitad entre Ayuntamiento y los Caballeros de la Junta del Vino.

Pero este año habria otro motivo que levantaría las quejas de las Ordenes, y fue el nombramiento como predicador para el segundo día de rogativas a un hermano del deán de la Colegial, al jesuita José Fabiani, lo que significaba quitar un puesto al predicador de las otras ordenes. La designación del jesuita y el hecho de ser el Monasterio de la Santa Faz el unico convento incluido en la Real Dotación, motivaría nuevos resquemores entre el resto de las ordenes, que posiblemente verían un cierto dominio de la familia Fabiani dentro de la iglesia alicantina, con el deán Tomás Fabián en la Colegial, José Fabiani en la Compañía y la tía de ambos como abadesa de la comunidad del Monasterio de la Santa Faz. Si todo esto fuera poco, el jesuita dedicaria su panegírico a defender el culto de Latria debido a la Santa Faz, algo abolido por Ujrbano VIII ciento treinta años antes.

A partir de 1761 se iniciaba un período de disputas que duraria hasta 1774. La Polémica entre Sales y Fabiani finalizaba a finales de 1764; este mismo año, franciscanos, agustinos, capuchinos, carmelitas y dominicos se negaban a acudir a la procesión de rogativas, en 1767 se decretaba la expulsión de los jesuitas, y en 1774 , cuando el deán Tomás Fabián ya había desaparecido, un grupo de canónigos intentarían adquirir unas preeminencias sobre la reliquia que nunca habían poseido.

\section{El sermón de 1760}

El panegirico pronunciado por Fabiani aquel 5 de marzo de 1760 fue publicado por el Ayuntamiento en 1763 y muy pocos meses despues se interesaban por su contenido algunos seguidores de aquel criticismo histórico que el deán Martí había depositado en sus discipulos Gorochán, Tosca, el trinitario Miñana y sobre todo en el por aquel entonces joven Mayans, quien sería ahora, cuarenta años después, el iniciador de la disputa entre el presbitero valenciano y el jesuita alicantino.

Pero llegado a este punto debemos aclarar en primer lugar que lo que conocemos como Polémica Ilustrada, no fue otra cosa que una crítica histórica a las aseveraciones realizadas por el jesuita Fabiani. En realidad no fue más que el contraste de dos filosofias, el juicio crítico de un clérigo secular a las afirmaciones de otro regular, dos formas de pensar diferentes: el racionalismo frente a la escolástica; la escuela del deán Marti, heredada por Mayans, frente a la jesuítica. Sin duda el deán alicantino había transmitido a sus discipulos, además del criticismo histórico, su acendrado antijesuitismo ${ }^{\circ}$.

Los protagonistas, al menos aparentemente, fueron dos clérigos, pero en el trasfondo de la polémica, subyacía además de la crítica histórica, el problema de las 
luchas de escuelas religiosas. Desde esta óptica podremos contemplar el problema con mayor objetividad, sin la distorsión que podria aparecer al enfocarlo desde el prisma de la negación de unas creencias religiosas.

Veamos to que indican los documentos y conozcamos a las personas que quedaron a la sombra de la polémica.

El sermón de Fabiani fue uno más de los que se predicaban en aquellos años: largo en su exposición, construido mediante una introducción explicativa en la que se detallaba el culto a los santos y reliquias, su núcleo exaltaba la devoción pública al asegurar que la reliquia alicantina era una de las tres impresas en el lienzo verónico y respondiendo así a los reparos que de su autenticidad había realizado "la authoridad de los Ilustrísimos Gonzaga y Vuadingo"7.

Si el sermón hubiera acabado en el púlpito, posiblemente nada hubiera sucedido, pero tras concluir Fabiani su Apostrophe al M.I. Magistrado de Alicante y a todos sus Horadisimos Ciudadanos y Habitadores ${ }^{\gamma}$ y dotar al texto de sus fuentes documentales. el sermón fue impreso y dado a conocer.

Detengámonos un momento para fijjar la atención en la persona de Fabiani, pues será de gran importancia para llegar al fondo de la polémica.

Era un hombre de la Compañía "minimo de los moradores de este Real Colegio" ${ }^{\prime \prime}$ y los jesuitas estaban siendo duramente denostados por las demás Ordenes religiosas, que conseguirian verlos en el exilio un lustro más tarde. Pero además era italiano en su fuero interno. De ascendencia italiana, sería el único miembro de la familia que no quiso castellanizar su apellido, como hicieron sus hermanos Juan Bautista Fabián, cónsul de Génova en la Ciudad al suceder a su padre, o Tomás Fabián, deán de la Colegial.

También las mujeres de la familia suprimieron la vocal finai del apeilido: primero su tia la madre sor Ana del Santisimo Sacramente y Fabián, profesa en el Monasterio en 1710, y abadesa durante el trienio 1753-1756. Luego tomaban los votos en el convento su hermana sor María Francisca Fabián (Rosa Maria en el siglo) en 1725 y más tarde, en 1744, profesaba su sobrina sor Ines Antonia Fabián.

Tampoco este gesto italianizante de Fabiani, levantaria muchas simpatias en 1763, años en que todos los males de la Monarquía era achacados a los italianos que rodeaban a Carlos III, especialmente a Esquilache. Fueron factores que contaron en la polemica.

Pero volviendo al sermón impreso en 1763, ¿qué podía escribir el padre Fabiani en un sermón de rogativas, si su interés era incrementar la fama del Monasterio de la Santa Faz y de la Reliquia custodiada por miembros de su familia? 
El mismo jesuita no ocultaba sus intenciones cuando se mostraba extranado de que hasta entonces:

"...no se haya escrito algún papel, que sólida y sencillamente expusiesse las noticias del distinguido y particular favor que la Divina Magestad, se dignó hacer a Vuestras Señorías Muy Ilustres y a todos los Habitadores de este floridíssimo País, embiándoles (por médios, tanto más dignos de atribuirse a su infinito poder. quanto menos tienen de naturales, y más se esconden a la inteligencia humana) ${ }^{10}$.

Fabiani intentaba justificar esta carencia de escritos sobre el Monasterio." porque la fe en la Reliquia se había transmitido de padre a hijos y esto calaba mucho más en los alicantinos que las palabras o escritos que pudieran ofrecerles, lo que habría propiciado el descuido de:

"Authenticar en debida forma tantas gracias y maravillas como desde entonces y en los tiempos presentes hemos experimentado de Nuetro Amabilisimo Redemptor, por medio de esta su Santísima $\mathrm{Faz}^{1+12}$.

El jesuita no ocultaba que había escrito la Disertación comprometido por "personas de mucha literatura y muy amantes del honor", quienes le encargaron escribir lo que todos deseaban pero nadie habia realizado, como tampoco disimulába su deseo de agradar a las ciases rectoras alicantinas y cantar los muchos meritos de estas tierras, en clara muestra de la elección divina de Alicante, donde dejó:

"... en prenda de su distinguido Amor, qual es el propio Retrato de su único Hijo hecho Hombre por nosotros y Redemptor del mundo"i3.

Cabe preguntarse cómo compuso el padre Fabiani la Disertación. la documentación utilizada y los testimonios empleados. Sin duda debió conocer la Justificación jurídica realizada durante la última década del siglo anterior, pero no en su totalidad, pues solo citaba los informes técnicos de los pintores:

"Pero es muy cierto que huvo tal instrumento público, como lo demuestra el Dr. don Pedro Maltés, Generoso, en su Discurso Histórico-Juridico, impreso en Alicante y presentado al que entonces era Obispo de Orihuela, el llustrísimo señor don Antonio Sánchez del Castellar"'i4.

Sobre la existencia del primitivo Rezo, muestra claras sus fuentes. Consulta la Crónica de fr. Marcos de Lisboa, General de la Orden de menores y 
posteriormente obispo de Oporto. Al dominico fr. Vicente Domenech y a los franciscanos fr. Antonio Juan Andreu y al padre Francisco Gonzaga.

Asi nacian en la tradición alicantina nuevos milagros desconocidos por Bendicho un siglo antes. De las Crónicas antiguas de fr. Marcos de Lisboa, provenía el milagro realizado al curarse el caballero impedido tras la invocación de las religiosas que iban a tomar posesión del Monasterio. Igual origen tuvo la reconciliación entre los dos emisarios enemigos frente a la cruz de Fusta.

Del dominico fr. Vicente Domenech arranca la confusion de fr. Benito de Valencia por fr. Francisco Bendicho, de Valencia, ${ }^{i 5}$ y lo mismo sucedió con el error en las fechas de los milagros, confundiendo "a ocho días después" del 17 de marzo, con el día 25 y el siguiente el 2 de abril, cuando del Rezo citado por Bendicho, se desprende que los prodigios fueron el 17, 24 y 31 de marzo.

Pero si estos pequeños deslices carecían de importancia, pasando desapercibidos hasta el siglo pasado, ${ }^{16} \mathrm{e}$ incluso enriquecieron la tradición Verónica con nuevos aportes prodigiosos, no ocurrió igual con el intento de justificar la existencia histórica de la mujer Verónica y el papel representado en la Pasión de Cristo. Creemos que el primer error cometido por Fabiani para demostrar la autenticidad de la Reliquia, fue rebatir la Crónica del padre Gonzaga, Generai que habia sido de los menores y autor de la Historia Seráfica de la provincia de Valencia, cuando con anterioridad se había basado en esta obra para justificar en el capítulo anterior, la veracidad de los prodigios acaecidos en 1489. Había tomado lo que le interesaba de la obra de Gonzaga y desautorizaba lo que no le convenía:

"Oponerse contra esta verdad, la authoridad de los Ilustrísimos Gonzaga y Vuadingo, con la de otros que lo trasladan de estos. diciendo que la Santa Faz de Alicante está impresa sobre tela de seda, o sea tafetán. Estas son las palabras del Ilustrisimo Gonzaga: Verónicae serico impressam. Mas verdaderamente no es asi, sino que se ve impresa en tela de lino, o quanto más de finisimo algodón, al modo de una finisima gasa. Lo qual está patenie a quantos miran de cerca la Santísima Faz, descubriéndose sin dificultad los hilos cruzados de la trama y urdidumbre en aquella forma que les da la textoria. Sobre el engaño de esta oposición han caminado quantos, sin embargo de contextar y referir los Milagros ya narrados y especialmente el de la aparición de las otras dos Faces, se persuaden o no quieren asentir, a que esta de Alicante sea la tercera y original como la de Roma y de Jaen. Si la huvieran mirado y atendido como lo han hecho tantos otros, huvieran salido fácilmente de su engaño, y sabiendo como se sabe que la que havía en Jerusalen, no se halla en aquella Santa Tierra y sólo queda la tradición de haver sido trasiadada a Roma. 
creerian con nosotros y afirmarian sin duda que es esta la de jertisalén y por consiguiente una de las tres"17.

El jesuita intentaba confirmar su idea presentando como prueba el testimonio firmado por don Fernando Valero en 1689, como informe técnico para la solicitud del Rezo.

Pero al asegurar que la Santa Faz del Monasterio de Alicante era una de las estampadas en el velo Veronico, implicaba la aceptación de la mujer Verónica como personaje histórico y sobre esto había diferentes opiniones dentro de la misma iglesia, no digamos entre los partidarios de la crítica histórica.

Fabiani intentaba demostrar la existencia de esta mujer "como. cosa ciertísima,aunque no consta del Evangelio, pero si por tradición de los Santos Padres" ${ }^{18}$ y para ello recurría a diversos autores que lo admitían en sus obras, como el teólogo jesuita padre Teófilo Raimundo".

Pese a que la figura Verónica no aparecia en los Evangelios ni en el Martirilogio Romano, el jesuita alegaba que en este último, no aparecían todos los santos, como en el caso de San Nicolás Peregrino, que sin estar citado, era reconocido por el cardenal Baronio.

Basándose en antiguos misales alemanes del siglo XVI, en los que aparecía una "Missa de vultu Sancto seu Verónica", y en el testimonio de Jaime Gretser en su tratado "Imaginibus non manufactis", aseguraba que en Alemania existia la tradicion de colocar a espaldas del altar Mayor, pinturas de la Verónica, de donde se deducia que Santa Verónica y Santa Faz no era una misma cosa, y que el confundirlas habia sido un problema de metonimia, es decir de designar al autor por la obra o el signo por el significado ${ }^{20}$. Fabiani quería señalar más, y declaraba que la Santa Faz había quedado impresa en el velo de una mujer:

"... que muchos quieren que fuesse aquella misma a quien curó Christo del fluxo de sangre con el contacto de fimbria. o sea orla de su vestido, como cuenta San Lucas, Cap. 8. 4. 44 ... y llena de compasión y agradecimiento a su Bienhechor Jesús, le ofreció y presentó el lienzo en el día de su Pasión"2!.

En apoyo de su teoría el padre Fabiani acudía a los testimonios de Pero Subetto, san Antonino e incluso al padre Bolando, como autor de la Historia de la santa Verónica.

Para el jesuita io importante era disociar los términos Verónica y Santa Faz,por lo que rebatía la teoría de que Verónica provenía de Vera Icon, y a su juicio sólo era debido a una transposición de letras: 
"... y sobre anagramas no se fundan, ni deben fundar las historias. principalmente en punto tan serio como este que ya no se puede dudar, sino con notable temeridad o de Pirronismo"22.

Fabiani necesitaba demostrar que Cristo habia fijado su rostro en los tres pliegues del velo Verónico ofrecido en su peregrinar hacia el Calvario, y para eso era preciso la existencia de la Verónica.

Y esta demostración era de gran importancia para la idea del padre Fabiani. pues conocía que la Iglesia admitia como verdadero el rostro divino guardado en Roma, pero no como impreso en el velo Veronico, sino en ia tela conque seco el sudor de sangre en el huerto de Getsemani, y de ser esto así solo podia haber una Santa Faz, quedando las muchas que se adoraban en meras copias de la de Roma.

El padre Fabiani no debió conocer la respuesta que 66 años atrás le diera a la Ciudad el deán Martí, al escribirles desde Roma en 1696, sobre la imposibilidad de conseguir el Rezo:

"Y a la verdad parece muy justa esta resistencia de la Sede Apostólica, en unas relíquias tan sospechosas como estas, de las quales tenemos otras tres en Baeza. Turin y Roma omitiendo otras que me acuerdo haver leido"23.

Si asi pensaba la máxima autoridad de la Colegial, cuando estaba recién nombrado para deán por Inocencio XIl, no podía ser por descreimiento, sino en reconocimiento de los abusos cometidos durante siglos por la Iglesia Romana, al conceder falsas reliquias.

Manuel Martí mostraría a su regreso de Italia un nivel intelectual que le convertiria en uno de los padres de la llustración valenciana y de la crítica histórica. Si el deán se había mostrado a lo largo de su vida como un critico histórico y enemigo de los jesuitas, ${ }^{24}$ la semilla quedaría en su discípulo Mayans, como podremos ver más adelante.

\section{La polémica}

Hasta aquí pudimos conocer la gestación de la Disertación Histórico Dogmática; cómo arranca de un sermón pronunciado para ensalzar y acrecentar la fe y devoción hacia la Santa Faz que se venera en el Monasterio alicantino. Con su publicación nacería la crítica por parte del presbítero Agustín Sales, Cronista de la Ciudad de Valencia y del Real Monasterio de la Santísima Trinidad, en dicha ciudad. 
Pero veamos cómo se inicia lo que denominamos "Polémica Ilustrada", entre Sales y Fabiani.

En agosto de 1763, el día 19, don Gregorio Mayans escribia a Sales, comunicándole que habia lilegado a sus oidos, la publicación en Alicante de un trabajo del jesuita Fabiani, sobre la Santa Verónica, para que si era posible le proporcionara un ejemplar:

"Ha salido una Disertación Histórico Dogmática sobre la Imagen de la Santa Faz de Alicante, escrita por el jeşuita Fabiani: papel desatinado. Si se vende cómpremele $V^{a} M d$., porque todo lo del Reino bueno i malo, deseo tenerlo"25.

Mayans mostraba su talante erudito, deseaba conocer todo lo del reino, bueno y malo, pero además le pedía al presbítero que estudiara la Disertación y le diera el juicio que de ella sacara.

Sólo cuatro dias más tarde, Sales tenia en sus manos la obra de Fabiani, la había leído y escribía su opinión a Mayans:

"...venero por lo que representa a la Santa Faz de Alicante, cuyo ejemplar embió que reserve para que no se perdiera en la encuadernación. No creo la Verónica en quanto mujer, sino en quanto Vera Icon impresa en el Huerto quando Iesu Christo sudó sangre, como escribe San Lucas: et factus est sudor eius sient gutta sang, etc. Niego los tres dobles del sudario, porque ninguin antiguo los tomó en boca. Concedo únicamente el verdadero sudario en San Pedro de Roma, porque convencen su identidad los monumentos de aquella antiguissima iglesia que en 1612 junto su doctisimo archivero Jacobo Grimaldi, i tengo en mi libreria i en especiales disertaciones de Honorato Santa Maria, Gerardo Casteel $i$ antes de estos, el obispo Simón Marjolo, que tengo assí mismo, i no tuvo presentes nuestro benditíssimo Fabiani.

De este recuerdo original de la Verónica, esto es, verdadera efigie de Nuestro Redemptor se sacaron en Roma las copias de las Verónicas que se veneran en Monpresil. Besón o Besansón. Cours $i$ Perigoral, en Francia. Las de varias poblaciones de Moscóvia i la singularmente venerada en la iglesia Mayor de su Capital (no hablo de la milagrosamente aparecida en Manzanera. de nuesira España), i la que venera Jaen i dió el Papa a su obispo don Nicolás de Biedma por 1386, de la que habló con mayor acierto Bartholomé Gimenez Patón, que el jurado Martín Ximeno quando se ensucia con el Chronicón de Juliano: $i$ la que venera Alicante, copia de la de Roma, que poco antes de 1489 trajo de 
aquella Ciudad Mossén Pedro Mena, Rector de la Iglesia de San Juan, como escrive Martín Viciana en su $3^{\circ}$ parte, i el padre fr. Gerónimo Sanchez del Castellar en su manuscrito del convento de Alicante, que componía por los años 1635, que tengo en mi librería con el sermón original, quando predicó a las religiosas de dicha Santa Faz, seguin el verdadero concepto de entonces, de ser copia de la de Roma. De todas estas noticias careció el insigne Fabiani para su Disertación. fundada sobre principios falsos $i$ llenos de simplicidad. Dígame $V$. Md. si hago buena critica en este asunto, i si no recibiré pacificamente la carga que V.Md. me diere $^{120}$.

De esta forma comenzaba la polémica. Como se puede comprobar no era más que la opinión de un religioso de la corriente llustrada, sobre las afirmaciones publicadas por otro religioso que no tenia sus mismas ideas.

Sales dejaba claro que veneraba a la Santa Faz de Alicante por lo que representaba, el rostro de Cristo impreso en el huerto, según testimoniaba el Evangelio de San Lucas, es decir como Vera Icon.

Lo que negaba totalmente el presbítero era la existencia histórica del personaje Verónico de la Pasión y por tanto, el que hubiera quedado impreso el divino Rostro en los tres dobles del velo. Para fundamentar su juicio,daba cuenta de una serie de tradiciones en diversas iglesias europeas en las que se veneraba la Verónica, ${ }^{2 i}$ pero siempre como copias de la romana, e incluso citaba el sermón de fr. Jerónimo Sánchez de Castelar dirigido a las religiosas del Monasterio alicantino, cuatro años después de ser abolido el Rezo primitivo, en el que aseguraba que la Santa Faz de Alicante era una copia de la de Roma.

El que hasta estos momentos se trataba sólo de enjuiciar las justificaciones dadas por Fabiani en su intento de demostrar que la Reliquia alicantina era uno de los pliegues Verónicos quedaba patente en la contestación dada por Mayans a la crítica de Sales. El 26 de septiembre de 1763 escribía don Gregorio:

"Se ha explicado Vmd en su carta con exquisita erudición $i$ mui maduro juicio. Unicamente dissiento en que pienso que en el mundo no ai Santa Faz que sea verdadera efigie de Jesú Christo Señor Nuestro. Porque San Agustín nos dejó escrito, que en su tiempo no avia efigie alguna verdadera de Jesú Christo ni de los apóstoles conservada desde el principio ¿de donde se prueva pues, que alguna es verdadera?. Primeramente, es inverosimil que nuestro Redentor se limpiase su sagrado rostro de manera que la efigie saliese eniera. Esto no es modo de limpiarse el sudor. Tal cosa no la refieren los Evangelistas, no los apóstoles que 
escrivieron Epistolas Canónicas, ni los Santos Padres de los primeros siglos. No los escritores eclesiásticos. No ai antigua $i$ legítima tradición que la aya conservado. Pienso pues que ha avido dolo pio para inducir a la devoción. I si no basta lo dicho, diga Vmd. que respondan a esto. En el Concilio Niceno Segundo assitieron más de 600 obispos que citaron todas las imágenes antiguas de que tenian noticia ¿dónde está la Santa Faz, ignorando su existencia i conservación toda la iglesia Cathólica?. A los que cita Vmd. que tratan de la voz Verónica, añada V[d]m. a Gil Menagio en los Orígenes de la lengua Francesa, donde está muy erudito" 28 .

La erudición de Mayans quedaba de manifiesto y su criticismo histórico heredado del deán Martí, le llevaba a no admitir hechos sin el previo examen de la posibilidad de su conocimiento $y$ de las fuentes que lo justificasen. Por eso rebatia algunos puntos al propio presbítero, negando la autenticidad de cualquier Santa Faz, incluida la de Roma.

No basaba sus afirmaciones o negaciones en tradiciones o Cronistas religiosos como habia hecho Fabiani e incluso el mismo Sales. Mayans se remitia a escritos de san Agustín, a los Evangelistas, Epistolas Canonicas, escritos de los Santos Padres, es decir a las fuentes primigenias, y sobre todo como hombre llustrado, a la razón. Por eso se detiene en la imposibilidad de que un rostro al que le secan el sudor, pueda dejar gravadas sus facciones, pues "este no es modo de limpiarse el sudor". Dentro de una misma linea de pensamiento, Mayans representaba la razón y Sales la fe.

Como dijimos anteriormente, pensamos que la polemica no se hubiera suscitado y todo hubiera quedado en las opiniones expuestas en la correspondencia intercambiada entre don Gregorio y el presbitero Sales, de no intervenir otros factores que enturbiaron la disputa. Pero en 1763 se realizaron nuevas rogativas y Fabiani era designado otra vez, como predicador para el primer dia con el consiguiente perjuicio para las demás Ordenes, que se limitaban a acudir tras la hora de Vísperas a la Colegial, para adorar a la reliquia guardando el orden de antigüedad.

A finales de septiembre de 1763 se interesaban por el escrito de Fabiani algunas Ordenes religiosas. cuyas diferencias con la Compañía se venian arrastrando desde años atrás. Iban a entrar en juego las escuelas y los intereses entre las órdenes religiosas. Carmelitas, Trinitarios y miembros de otras religiones, pidieron a Sales que les enviara su juicio sobre la Disertación del jesuita.

Los Trinitarios de Játiva, de cuyo Monasterio estaba escribiendo en aquellos años Sales su historia, solicitaron por medio del prior fr. Tomás de Calabuig, la crítica del presbítero sobre el escrito de Fabiani. El 27 de septiembre, Sales remitía 
la respuesta:

"Reverendísimo P. Ministro. Mui señor mio: Recibi el papel de V. Rma. por el que desea saber mi dictamen sobre la Disertación del Padre Joseph Fabiani de la Compañía de Jesís. I no pudiéndome negar por mi público oficio, manifiesto con ingenuidad a $V$. Rma., el concepto que hice del assunto. apenas me lo regaló cierta persona noble i avia insinuado ya por el correo día 23 del presente a un sugeto mui sabio del Reino, que me hizo la misma pregunta. Digo pues $P$. Rmo. que venero por lo que representa a la Santa Faz de Alicante. No creo la Verónica en quanto mujer que saliera a la calle de Amargura i diera su toca al Señor, para impiar su rostro, porque es história tan incierla que san Buenaventura, sobre tan comtemplativo tratando de la Cruz a cuestas en su Vita Christi. no la tomó en pluma por que se imaginó después de su tiempo no sin notables contradicciones. I el padre Hensehenio que la creyó, estando después en Roma año 1661, oyó los desengaños de Juan Holstenio Bibliothecario del Vaticano, y supo cómo el Cardenal Barónio avia rechazado a esta mujer por imaginaria en la corrección del Martirilogio. Creo la Verónica en quanto Vera . Icon como juzgaron Benito Arias Montano, Gil Menario, el Brocense, Juan Mabillón. Daniel Papebroquio, Honorato de Santa Maria. Filemont, Natal Alex i Gerardo Castiel, varones sumos. Pero impresa en el Huerto (según la tradición más antigua, que con aprecio abrazó el insinuado Papebroquio, confirmada con la Oración de Constantino Porfirogénito) quando.Jesu Christo sudó sangre... Niego los tres dobleces del sudario porque ninguno antiguo lo tomó en boca. Concedo únicamente un verdadero sudario original en San Pedro... Ni son menester tantas funciones para dejar a la Santa Faz de Alicante en el sólo estado de la adoración de Latría respectiva devida a qualquier imagen de Jesu Christo recientemente pintada. La adoración pende principalmente de la intención, la qual deve ser más viva en la imagen original de la Santa Faz por el contacto fisico con el Rostro del Señor que con las comúnmente pintadas. I haciendo el Padre la adoración igual. es indicio que nada cree de lo que intenta persuadir; $i$ assi le deven mui poca merced los alicantinos, pues quita a su Santa Faz, aquella cierta especie de mayor adoración que da la intención por el original que quiere provar; bien que en sí, la Santa imagen. aunque mui digna de tanto respeto, por los continuados milagros con que hace bienaventurada a la Ciudad de Alicante, que fue la antigua Lucentia de Mela, i Lucentum de Plínio. Pregíntame en su papel $V$. Rma. si la Santa Faz objeto de la Disertación, es una 
de las tres que nuestro redenttor imprimio en el lienzo de la Verónica i se conservava antes en Gerusalén. De lo dicho asta hora puede V. Rma. colegir las respuestas, $i$ es que no es una de las tres, porque no huvo tres, sino una en Gerusalen, que es la que se adora en San Pedro de Roma, de la que se copiaron las que de tiempos modernos se veneran en Gerusalén, Jaén, Alicante... y otras partes. I que no se dice Verónica porque huviese tal mujer, por que la Santa Faz se imprimió en el Huerto. Ubi milla matrona Adorat (dice el gran Pepebroquio) quod sudarium ei porrigeret..."

Sales daba al fraile de Játiva similar respuesta que a Mayans, pero aquí hablaban dos clérigos y remarcaba que no era la adoración de Latría la que debia darse a una reprodución del original de Roma, sino otra menos viva. Este juicio serviría para acusar al jesuita de relajar las costumbres y del flaco favor que hacía a los alicantinos, pues siendo lo más importante de la oración la intención del devoto, esta intención se perdía al ofrecerle a la Santa Faz una adoración mayor de la debida.

Sales olvidaba que roda sacralización de un objeto, viene dada por la devoción popular manifestada por todo un pueblo, mientras que el reconocimiento oficial de la Iglesia suele llegar cuando a ésta le interesa. Pese a esta omisión el presbítero reconocia que la Reliquia conservada en el Monasterio alicantino era digna de tanto respeto por los contínuos prodigios y beneficios que había deparado a la Ciudad.

Con esta carta en manos de los Trinitarios lo que podía haber quedado en meros comentarios entre dos Ilustrados sobre el escrito de Fabiani, se convertiría en la verdadera polémica. La intervención de otras Ordenes religiosas en oposición a los jesuitas y la divulgación de las cartas harian llegar la polémica hasta el mismo Alicante.

No le habia gustado a Sales que don Gregorio le rebatiera la autenticidad de la Santa Faz de Roma y quiso defender sus ideas, escribiendo a Mayans el 7 de octubre de 1763 .

"No puedo consentir en que en el mundo no aya Santa Faz que sea verdadera efigie de Christo Señor Nuestro. Entiendo que repugna la antigüedad. San Irineo contemporáneo de dichos apóstoles o casi... insinia las imágenes de Jesús i Paulo. Tertuliano... habla de la imagen del Pastor que se pintaba en los cálices. Por coetáneos sabemos que el emperador Alejandro Severo, tenía también en su oratorio la Efigie de Christo ... Eusebio Cesariense asegura como testigo ... que vió en Cesaréa de Felipe, en estátua de bronce o efigie de la Faz del Señor ... hecha en tiempo de 
Christo i no menos retratos de San Pedro i San Pablo. Conque San Agustin no pudo decir nunca que en su tiempo no avia efigie alguna verdadera de Jesu Christo ni de los apóstoles ... quando en su libro l.de Consensu Evang. Cap. $X$. habla expresamente de pinturas de Christo. de San Pedro i San Pablo ... El mismo Concilio asegura que havía otras imágenes (en el omitidas...) que fuera una de ellas la Santa Faz de San Pedro de Roma, lo asegura la oración que publicó de ella Constantino Porfirogénito i imprimió Lipómano, $i$ assi no ignora su existencia la Iglesia Católica. No es inverosímil que Christo dejara su rostro estampado en un lienzo saliendo entera la efigie. Por que en este Concilio Niceno II. toda la iglesia, toda la iglesia, oyó que aplicando Christo un velo a su rostro dejó en el estampada la imagen de Cesaréa. Y aunque nada dicen los Evangelistas, sabemos que no lo escrivian todo como asegura San Juan, C. 21 v. 25. Nada dicen de la Efigie de Cesaréa i fue mui cierto. I assi de las Faces de Christo ai constante i legítima tradición conservada hasta el presente. Si bien tales primitivas imágenes empezaron a adorarse en los templos después que Constantino dió la paz a la Iglesia. Hasta este tiempo en los oratorios o templos de los Christianos, no avía otra imagen que la Cruz,de lo que son testigos Zefiro, Minucio Félix $i$ Tertuliano".30.

El presbítero continuaba dando cuenta a Mayans de la peticion que le habia realizado fr. Tomás de Calabuig, como prior del Monasterio de Jativa y la respuesta que el había ofrecido sobre la Disertación de Fabiani, asi como de las intenciones del fraile Trinitario, quien quería realizar copias de la critica para entregarlas al señor Albornoz, y que éste, con su sobrino don Pedro de Albornoz las repartiera a Carmelitas y otros frailes que habian prometido distribuirlas en Alicante:

"Conque el padre Fabiani (a quien nunca he tratado ni conozco, sabrá mucho más de lo que ignorava en el asunto"sit.

La polemica había tomado un rumbo distinto al inicial. No se dilucidaban ya, unas afirmaciones o un juicio crítico sobre la Disertación, sino que se intentaba acusar de laxo al padre Fabiani como miembro de la Compañía.

Es curioso comprobar cómo, cuando Sales intentaba demostrar ante Mayans que la Santa Faz de Roma era la única verdadera, recurria a los mismos errores que el jesuita: los evangelistas no lo escribieron todo, la tradición de la iglesia ... la fe quería imponerse a la razón.

Los argumentos dados por el presbítero no convencieron a Mayans, quien tres, días más tarde le contestaba: 
"Ha compensado V. Md. el silencio de la semana antecedente con la copia de erudición de su última carta, acompañada de otra festiva que causará harto disgusto al P. Fabiani, si llega a su noticia. Me parece muy bien lo que V. Md., dice de la Verónica, por ser lo mismo que yo sentia; $i$ añado, que en lo que toca a admitir Santa Faz original conservada desde Jesu Christo Señor Nuestro, no quiere V. Md. ser tan crítico como suele, quizá por miedo de los crédulos, no sea que le traten como iconoclasta. Los testimonios que V. Md., apunta en su carta son mui buenos para convencer esta heregía, pero no para provar que aya efigie original de nuetro Redentor. San Irineo en ei libro I, contra Hoereses, Cap. 24, alias 23, habló de las imágenes de Jesu Christo que tenían los gnósticos, embusteros de primera clase. Tertuliano De pudicitia, cap.7 i 10, de las imágenes del Buen Pastor, gravadas en los cálices. los cuales probablemente serian recientes por haverse variado su materia, i no consta que aquellas fueran verdaderas efigies. Lo que dijo Lampídio del Lavario de Alejandro Severo. es esto: in quo et divos principes,sed optimos electos et ánimas sanctieres, in queis et Apolonium et puantum scriptor suorum temporum disit, Christum,Abraham et Orpheam, et huiusmodi Deos habebat, ac maiorum effigies. Podia lener las verdaderas de los principes sus antecesores, de alguno de sus mayores, pero no la de Habrahan ni de Orfeo, i jcómo se provara que era verdadera la de Jesu Christo, si de ningún Christiano se afirma que la tuviese verdadera?. La expresión de que se valio Eusebio Cesariense en el lib. 7 cap. 18. hablando de la estatua de Cesaréa, es ésta: Hanc statuam Jesu Christi speciem refert aiebant. Esto es, los gentiles. Ellos lo decian, pero ¿como avian de ser en esto más diligentes que los christianos?. En fin yo creo a San Agustin, lib. 8 De Trinitate, cap. $4 n^{\circ} 7$. donde dice que en su tiempo no avia retratos algunos verdaderos de Jesu Christo, sino imágenes formadas por fantasía. ¿Dónde está pues i como se conservó la Santa Faz, no aviendo testimonio más antiguo que el de Constantino Perfirogénito, escritor del siglo duocécimo?. Si V.Md. me dice que se lo cree, yo lo dudo i pienso, como dige al principio, que $V$. Md. no quiere pelear con gente superticiosa"iz.

Mayans rebatía así las alegaciones del presbitero, que criticando a Fabiani sus afirmaciones y método sobre la Verónica, defendía con similares argumentos la autenticidad de la Santa Faz de Roma.

Don Gregorio daba una serie de argumentos sólidos y convincentes y sólo aceptaba las palabras de San Agustín. Acusaba a Sales de no ser tan critico en ese punto como lo había sido con el escrito de Fabiani. 
La crítica a la Disertación Histórico Dogmática de Fabiani, que habia surgido entre Mayans y Sales, había desbordado los límites en los que se iniciara. Fray Tomás de Calabuig seria el encargado de propagar los comentarios del presbitero a través de la familia Albornoz, repartiendo entre los conventos alicantinos gran número de copias, criticando al jesuita. Entre los frailes más activos se mostraron los Carmelitas, quizá por aquello de la competencia, ya que por esos años habían creado en su convento una escuela de primeras letras ${ }^{33}$.

A la critica de Sales se le dió toda la publicidad necesaria para desacreditar a los jesuitas, llegando a circular "mas de trescientas copias de su escrito que fiuc leido en las tertulias y estrados ante personas de tmo y otro sexo ${ }^{n+5}$.

El propio Viravens reconocia haber visto uno de esos ejemplares manuscritos firmados por el presbitero Sales de Valencia, en el archivo de don Juan Bautista de Besecort, conde de Santa Clara.

El daño estaba hecho. El padre Fabiani quiso enfrentarse a la critica de Sales, pero imaginando que el ataque, en el fondo, iba dirigido contra los jesuitas, escribió "La Disertación de la Santa Faz de Alicante. con Reflexión sobre Reflexiones", bajo el seudónimo de Dr. Basilio Ponce de León, presbitero. siendo impresa en Murcia en 1764.

La defensa del supuesto Ponce de León dándole la razón a Fabiani y rebatiendo a Sales sus alegatos, estaba dividida en nueve puntos y en ellos intentaba desmontar las críticas del valenciano. Ya en la introducción, justificaba las acusaciones de Sales como:

\footnotetext{
"Achaques de la edad en que vivimos, donde se gradian de ingeniosos aquellos génios que, mal contentadizos con to que escriven otros, dedican toda su ciencia y estudio a mendigar opiniones de meras probabilidades, por oponerse a las sentencias mas corrientes" ${ }^{135}$.
}

No dejaba el autor la defensa de los jesuitas, a quien sabia centro del ataque de otras Ordenes, por lo que hacia confesar al supuesto Ponce de León, su formación jesuítica:

"...el verme hacer oficios de maestro, siendo yo tan discípulo de la Compañia de Jesuis, como que cursé por muchos años sus Escuelas, archivos de sabiduria, exemplo de Política Christiana y Religiosa que dixo Paulo Quinto en su Bula: Quantum Religio Societatis Jesu in Ecclesia ad fidem pietatis, et Religionis augmentum prócerit, et in dies magis proficiat nos ipsi scimus" ${ }^{136}$. 
A lo largo de las reflexiones, su autor iba desmontando los alegatos del presbítero Sales.

Al no reconocimiento de la mujer Verónica, porque san Buenaventura o los santos Padres no daban cuenta de ella en sus escritos, Ponce de León anteponía que tan poco hacían constar que la Virgen:

"... saliese al encuentro de Jesús en la calle de la Amargura, y no obstante esto, todos creemos este encuentro y suceso, y decimos con el mismo P. Suárez: Non tamen est rejiciendum ${ }^{1.37}$.

El personaje Verónico estaba citado por san Metódio casi un milenio antes del nacimiento de san Buenaventura. Adricomio, ilustrador de Tierra Santa, también Io citaba y el mismo Juan Bolando escribia sobre elìa en su monumental obra.

No podía resistirse Ponce de León a señalar que los jesuitas habían marcado el inicio de la justificación histórica de reliquias y vidas de santos, en la escuela de Amberes, con el padre Iteriberto Rosveydo, iniciador del Acta Santorum y sus sucesores Bolando; Henschenio, Daniel Papebrochio y otro muchos bolandistas que habían dedicado sus vidas a escribir las vidas de los santos:

\begin{abstract}
"Rechazando lo falso y lo inventado, admitiendo lo verdadero y dexando en los términos de dudoso o no bien averiguado, lo que no pudieron sacar de este estado; siempre dispuestos y prontos a retractarse de lo que huviesen escrito e impresso, si se les hiziese constar haverse engañado"138.
\end{abstract}

Negaba la posibilidad de que el "padre Hensechenio quedara desengañado en $166 I^{\prime \prime}$, con las demostraciones del bibliotecario del Vaticano y la corrección del Martirilogio por parte del cardenal Baronio, pues resultaba muy extraño que el primero no hubiera comunicado su desengaño a un compañero de trabajo como era el padre Bolando, quien aseguraba' en su Historia de la santa Verónica, que era tradición cristiana.

- En cuanto que Baronio rechazase del Martirilogio a esta mujer le parecía inverosimil, ya que sería incomprensible esa actuación cuando el mismo cardenal habia escrito en el tomo I Annual ad annum Christi, 34. Tiberii autem, $18 n^{\circ} 138$, que era diferente dei sudario con que se envolvió la cabeza de Cristo en el sepulcro:

"...aquél que Berenice aplicó a la Cara del Señor llena de sangre $y$ de sudor, y retuvo en si la efigie del mismo Rostro del Señor, como lo tiene la Tradición Christiana y lo atestigua un librito manuscrito de la tradición que se hizo en Roma, a dicho sudario y se guarda en la Biblioreca Vaticana"39. 
Mayor espacio dedicaría Ponce de León a contestar "a nuestro Doctor valentino", su creencia en la Verónica en cuanto a Vera Icon. Aceptaba la palabra como producto de un anagrama, pero no porque Verónica signifique Santa Faz o verdadera imagen, sino que del juego de letras de Verónica se había obtenido Vera Icon, y se le daría a la mujer como poseedora de esa verdadera imagen. Seria un caso similar al de la casa de la anunciación de la Virgen trasladada a Italia por los ángeles en 1294. No se conocería como "casa de la Virgen", sino que tomaria la denominación de su nuevo asentamiento en las tierras de Loreta y pasaria a llamarse Casa de Loreto o Santa Casa de Loreta ${ }^{40}$.

Curiosamente Ponce de León atestiguaba sus ideas poniendo como ejemplo a Mayans:

"Al Doctor don Gregorio Mayans, honor de la República Literaria y gloria muy particular de la nación Valenciana, en su libro que intituló el Orador Christiano, al $n^{\circ} 25$ del diálogo primero: Porque quien hay (dice el Eruditísimo señor Mayans) que no mude de significación (esto es transnominación) de las cáusas a los efectos. como leo a San Pablo por sus Epístolas, de los efectos a las causas como, la guerra todo lo perturba, por los que guerrean, de los sugetos a los adjuntos, como Valencia por sus habitadores. $Y$ assi también del possehedor a la casa poseida, como arde Ucalegón, por la casa de Ucalegón; La Guzmana, por la Heredad de guzman o de los guzmanes, y assi otras cosas casi infinitas de esta especie de transnominaciones" ${ }^{\prime 1}$.

El autor de las Reflexiones dedicaba el siguiente punto a rebatir la idea de Sales, sobre la impresión de la Faz de Cristo cuando sudó sangre en el huerto, según comentaba San Lucas: Et factus est sudor ejus sicut guttae sánguinis.

Ironizaba contra Sales, reconociendo que era la primera vez que tenia noticia de semejante hecho, sintiendo gran pesar que el valenciano no citara autor y obra que asegurara que a Cristo se le enjugó el sudor en el huerto. Contraponía dos argumentos. Según San Lucas en el cap. 22, contaba que habiendo seguido los discípulos a Jesús, éste les dijo:

"Orad para yue no entreis en tentación, y se apartó de ellos quanto es un tiro de piedra, y puesto de rodillas oraba ... y entrando en agonia, oraba más prolijamente. Factus est sudor ejus, sicut guttae sanguinis decurrentis in terram"142.

Aseguraba que ningún evangelista citaba el hecho de que un discípulo de Jesús, estando lejos de èl, se acercara a enjugarle el sudor. Es más, según el mismo Lucas, cuando Jesús terminó de orar y se acercó a ellos los encontró dormidos. Y 
tampoco pudieron hacerlo tras ser despertados quid dormitis. surgite?, porque según el Evangelio venian ya a prenderle: Adhuc co loquente, ecce turba et qui vocabatur Judas.

A Ponce de León no le parecía creíble que en momento de tanto temor, le enjugaran el sudor y la sangre, posiblemente seca por el tiempo transcurrido; además y siguiendo a San Lucas, porque al terminar de orar "ya el Angel le havía confortado, y por consiguiente no duraba la agonia y sudor de sangre" ${ }^{n ;}$.

El segundo testimonio del autor rebatía totalmente la impresión de la Faz de Cristo en el huerto, pues siendo la única y verdadera, como atestiguaba Sales, la que se veneraba en Roma, en ella se mostraba:
"...la cabeza y frente con las señales de las espinas ... amoratada y denegrida la Cara, y en la mexilla derecha. a más de las liviaduras o moraduras, se descubre casi estampada la herrada mano de uno de los Ministros (según San Juan. al cap. 18) y en la otra mexilla muchas manchas de saliva ... la barba pelada y mu- chos cabellos arrancados ${ }^{\text {"44 }}$.

Si esto era así y el presbítero reconocía que la única Santa Faz verdadera era la de Roma, que había sido impresa en el huerto de Getsemaní, ¿cómo podían aparecer las señales de espinas en la frente y las huellas de los castigos, si durante la estancia en el huerto aún no había sufrido esos tormentos?.

La defensa de la Disertación se mantuvo costante, incluso con éxito durante las primeras cinco reflexiones, para empezar a decaer su argumentación sobre los detalles más recientes y perdiéndose a veces al intentar demostrar el camino seguido por la Reliquia hasta su llegada a Alicante.

Tampoco acertó al tratar del sermón de fr. Jerónimo Sánchez de Castelar a las Clarisas en 1635, cuando reconocía: "yo no lo sé ni he querido cveriguarlo". cuando le hubiera sido relativamente fácil relacionar el citado sermón, como justificativo de la actuación papal al suprimir el Rezo cinco años antes, mientras que en lugar de esto daba más valor al testimonio de Carlos II y las cartas escritas al duque de Medinaceli y al cardenal Cibo, sabiendo que este proceso no podía servir de argumento, pues pese a todas las recomendaciones, el rezo fue denegado por Roma.

Sin embargo parece acertar en su defensa al culto que se ofrecia a la Santa Faz, distinguiendo entre el culto de Latria absoluta y de Latría respectiva. Tampoco pudo evitar señalar su filiación ideológica cuando confiesa que era "muy Christiano, muy catholico, y sobre todo, es jesuita" 45 . 
Al final de las Reflexiones indicaba el motivo que llevó a Fabiani a ampliar un sermón, que de haber quedado como tal, no hubiera tenido lugar la polémica.

Este motivo no fue otro que durante la rogativa que se trasladaba a la Santa Faz a la Colegial en 1760 , se habían suscitado problemas sobre la veracidad de la Reliquia, a la que no debía darse culto de Latría respectiva. Estas dudas aparecidas en conversaciones privadas de personas "cristianas y católicas" que:

"... echasse sus acusaciones o agudezas bufonescas, destructivas de la devoción y sobradamente injuriosas a la Piedad Christiana..."

De ser esto cierto, Fabiani tuvo que componer su sermón en 48 horas, pues estaba nombrado predicador para el segundo día de esas rogativas o en todo caso adecuarlo a las circustancias y poder demostrar lo insensato de aquellas gentes, que precisamente eran religiosos.

Las Reflexiones terminaban recriminando los escritos del presbítero valenciano, porque:

\begin{abstract}
"Bien sabe $V . M d$. que el contradecir una pia creencia, aún quando no estribase en tan solidos fundamentos como ia que tienen los alicantinos ... no sirve sino para enfriar los ánimos de los fieles. llenarlos de dudas y tener (aunque falsamente) por hereges o sospechosos de heregía a los que se les oponen" ${ }^{147}$.
\end{abstract}

Daba por supuesto que Sales tenía consciencia, de que en historia, sobre todo si era historia eclesiástica, habian autores discrepantes y que de esa discrepancias al hacerlas públicas, solo podía nacer el mal, para la tradición cristiana, porque:

"... ¿qué obsequio haria a Dios, qué utilidad a los Fieles, ni qué crédito de Erudito se grangearia aquél que se tomase ia ocupación de escrivir contra la identidad del Sagrado Cáliz de Christo que se venera en Valencia? Y con tanto como he insinuado antes $y$ según otras noticias y observaciones que me tengo hechas, juzgo, que con mayor probabilidad se podría contradecir, de la con que se pretende quitar a los alicantinos la inveterada Tradición con que la Iglesia de Alicante muestra, que el Lienzo de Santa Verónica. estava plegado en tres doblezes ... y que una de esas tres es la que posee ..."

Las reflexiones de Ponce de León, tardaron muy poco en llegar a manos del presbítero Sales, quien debía estar informado de que el autor no era otro que el padre Fabiani, pues el 27 de abril de 1764, escribia a don Gregorio Mayans: 
"... el bendito P. Fabiani de Alicante ha impreso con glosas llenas de simplicidad $i$ rudeza mi carta contra la tradición de la Sania Faz, de que estan desatinados los alicantinos, por que con tal diligencia descreeran todos la persuasión vuigar. Conozco por ellas que ignora muchissimo aún de sus esortores domésticos. Le responderé concluyentemente, apenas tenga ocio para ello" ${ }^{149}$.

A partir de estas fechas no pudimos encontrar más testimonios de la polémica, por lo que desconocemos si Sales contestaria a Fabiani, como había comunicado a Mayans, pero lo que sí sabemos es que en la rogativa de 1764, las Ordenes religiosas citadas lanzaban un ataque contra la tradición verónica e indirectamente contra los jesuitas.

Ante la notificación de los regidores para que las órdenes religiosas acudieran a la Colegial donde debía formarse la procesión oficial que debia salir a recibir la reliquia, el prior de Santo Domingo se negó a acudir con su Comunidad. Fueron inútiles los intentos del Ayuntamiento por hacer desistir a los frailes, pero ante la insistencia municipal se vieron obligados a dar una explicación demostrando que todas las Ordenes estaban de acuerdo en no asistir, según demostraba la carta firmada y sellada por los conventos de San Francisco, del Carmen, Capuchinos, Agustinos y Predicadores ${ }^{50}$. El motivo alegado no sería otro que el desear el puesto que ocupaban los pescadores de la Cofradia de San Jaime.

Realizar la rogativa sin la asistencia de las Ordenes significaba romper la tradición y, lo que era más grave, el escándalo de los fieles que conociendo que los frailes habian propagado la falsedad de la reliquia, ahora se negaban a darle culto por falta de legitimación. La rogativa tuvo que ser aplazada. En realidad la negativa solo estaba motivada por que, desde cuatro o cinco meses atrás, los frailes venian repartiendo en Alicante los escritos de Sales contra Fabiani y la procesión estaba presidida por el hermano del citado jesuita ${ }^{51}$.

El triunfo de las Ordenes que acusaban de laxos a los miembros de la Compañía, quedó patente el siguiente año al ser nombrado para el sermón del día de la fiesta al trinitario fr. Tomás de Calabuig, prior de Játiva, a quien Sales había remitido el juicio crítico sobre la reliquia. Y no solo esto, porque en enero de 1766 el regidor Caturla informaba que:

"...según sujetos inteligentes, el sermón del dia de la Santa Faz predicado el pasado año por el Rvdo. P. fr. Tomás Calabug, trinitario era tan digno que debia imprimirse" ${ }^{\mathrm{S2}}$.

Pero hay más datos de que los jesuitas habian perdido la batalla: en 1767 eran expuisados de todos los territorios españoles, mientras que ese mismo año los dominicos inauguraban la ampliación de su convento y poco después, en 
1769, conseguian la concesión de las cátedras de Filosofia y Latin que hasta entonces tenía establecidas la Compañía.

Eran los últimos coletazos de la Polémica Ilustrada, una controversia que fue aprovechada por las Ordenes religiosas para socavar el dominio de los jesuitas. 
1.- MALTÉS, J.B., Hice Ilustrada. Hisroria de la Muy Nob̆le, Leal y Fidelisima Cindad de Alicante. Alicante, 1991.

2.- VIRAVENS Y PASTOR, R. Crónica de Alicante, Alicante, 1876.

3.- A.M.A. Arm. 5, Lib. 29, Fol. 77.

4.- A.M.A. Arm.9, Lib. 50, Fol. 10.

5.- A.M.A. Arm.9, Lib. 50, Fol.,11.

6.- MESTRE SANCHIS,A. Humanismo y Crítica Iistórica en los llustrados Alicantinos. Alicante, 1980, pág. 17.

7.- FABIANI, José. Disertación Historico-Dogmática sobre ia Sagrada Reliquia de la Santisima Faz de Nuestro Señor Jestu-Christo.... Murcia, 1763, pág. 43.

8.- Ibid. pág. 61.

9.- FABIANI, Ibíd. (En la dedicatoria a la Ciudad).

10.- FABIANI. Ibid.

11.- Hasta aquellos momentos sólo se habia escrito la Crónica de Bendicho, que permanecia olvidada en San Nicolás, y se estaba trabajando en la de Maltés.

12.- Ibid. supra.

13.- Ibid. supra.

14.- FABIANI, Op. cit. pág. 34.

15.- Reconoce Fabiani que algunos escritos sacados del antiguo Rezo rambien le llaman fr. Francisco Bendicho.

16.- Al tomar como fuente a Fabiani, don Rafael Viravens caera en los mismos errores, y esta idea fue seguida por autores posteriores.

17.- FABIANI, Op. cit. pag. 44 .

18.- Ibid. fol. 12.

19.- Fabiani cita el tomo Deu Homine, libro segundo del citado jesuita, a Malonio en sus Comentarios de la Sábana Santa, la Historia Antigua y Moderna de Palestina de Berdini, además del cardenal Baronio, Jacobo Pamelio y otros.

20.- El problema estaba en que cierta parte de la iglesia identificaba la imagen Verónica como ya Vera Ícon que Cristo había dejado estampada cuando sudo sangre en el huerto de los Olivos y esto nada tenia que ver con la mujer Verónica. 
21.- FABIANI, Op. cit. pág. 19.

22.- Ibíd. pág. 18.

23.- A.M.A. Arm. 11, Lib. 18, Foi. 170.

24.- MESTRE SANCHIS, A., Op. cit. pág. 29.

25.- B.A.H.M. $n^{\circ} 132$.

26.- B.A.H.M. $\mathrm{n}^{\circ} 30$.

27.- Como anotabamos anteriormente, siempre que Sales habia de ia Veronica to hace como verdadera imagen de Jesús. Por eso cuando Mayans niegue la existencia de esa Vera Icón, el Cronista de Valencia intentará demostrarlc con testimonios su veraciỏad.

28.- B.A.H.M. $n^{\circ} 132$.

29.- B.A.H.M. $n^{\circ} 30$.

30.- Ibid. supra.

31.- Ibid. supra.

32.- B.A.H.M. $\mathrm{n}^{\circ} 132$.

33.- VIRAVENS Y PASTOR, R., Op. cit. pág. 175.

34,- ibid. pag. 87.

35.- PONCE DE LEON. Basilio. (Seudónimo de Fabiani): La Disertación de la Santa Faz de Alicante, con Reflexión sobre Reflexiones. Murcia, 1764. pág. 2.

36.- Ibid. pág. 6.

37. Ibid. pág. 8 .

38.- Ibid. pag. 10.

39. - lbíd. pàg. 13.

40.- Ibíd. pág. 20.

41.- Ibid. pág. 18.

42.- Ibid. pảg. 25.

43.- Ibid. pág. 28.

44.- Ibíd. pag. 30 .

45.- Ibíd. pág. 66 . 
46.- Ibid. pág. 65.

47.- Ibid. pág. 68.

48.- Ibid. pag. 75 .

49.- B.A.H.M. $n^{\circ} 30$.

50.- A.M.A. Arm. 9, Lib. 54, Fol. 48.

51.- B.A.H.M. $n^{\circ} 30$.

52.- A.M.A. Arm.9., Lib. 56, Fol. 32. 